\section{Acknowledgments}

We would like to thank Marta Díaz Nieto, B.S. in Education, specialized in English, for her collaboration reviewing the abstract.

\section{REFERENCES}

1. LaFranchi S. Tiroiditis. En Kliegman R, editor. Nelson: Tratado de Pediatría. 19. a ed. Barcelona: Elsevier; 2012: 1975-7.

2. Fava A, Oliverio R, Giuliano S, et al. Clinical Evolution of Autoimmune Thyroiditis in Children and Adolescents. Thyroid 2009;19(4):361-7.

3. Caturegli P, De Remigis A, Chuang K, et al. Hashimoto's thyroiditis: celebrating the centennial through the lens of the Johns Hopkins hospital surgical pathology records. Thyroid 2013;23(2):142-50.

4. Skarpa V, Kousta E, Tertipi A, et al. Epidemiological characteristics of children with autoimmune thyroid disease. Hormones (Athens) 2011;10(3):207-14.

5. Marshall WA, Tanner JM. Variations in pattern of pubertal changes in girls. Arch Dis Child 1969;44(235):291-303.

6. Mayayo E, Ferrández Longás A, Labarta JI. Interpretación de las pruebas tiroideas. An Esp Pediatr 2002;56(Supl 4):42-52.
7. Alos N, Huot C, Lambert R, et al. Thyroid scintigraphy in children and adolescents with Hashimoto disease. J Pediatr 1995;127(6):951-3.

8. De Vries L, Bulvik S, Phillip M. Chronic autoimmune thyroiditis in children and adolescents: at presentation and during long-term follow-up. Arch Dis Child 2009;94(1):33-7.

9. Doeker B, Reinehr T, AndlerW.Die autoimmunthyreoiditis bei kindern und jugendlichen: linische und biochemische befunde bei 34 patienten. Klin Pediatr 2000;212(3):103-7.

10. Rother K, Zimmerman D, Schwenk F. Effect of thyroid hormone treatment on thyromegaly in children with Hashimoto disease. J Pediatr 1994;124(4):599-601.

11. Rallison ML, Dobyns BM, Keating FR, et al. Occurrence and natural history of chronic lymphocytic thyroiditis in childhood. J Pediatr 1975;86(5):675-82.

12. Demirbilek H, Kandemir N, Gonc EN, et al. Hashimoto's thyroiditis in children and adolescents: a retrospective study on clinical, epidemiological and laboratory properties of the disease. J Pediatr Endocrinol Metab 2007;20(11):1199-205.

13. Sclafani AP, Valdes M, Cho H. Hashimoto's thyroiditis and carcinoma of the thyroid: optimal management. Laryngoscope 1993;103(8):845-9.

14. Hung W, Anderson KD, Chandra RS, et al. Solitary thyroid nodules in 71 children and adolescents. J Pediatr Surg 1992;27(11):1407-9.

\title{
Osteomyelitis in burn children: Ten years of experience
}

\author{
María T. Rosanova, M.D. ${ }^{a}$, Carla Voto, M.D. ${ }^{a}$, Susana Carnovale, M.D. ${ }^{c}$, Nidia Tramonti, M.D. ${ }^{b}$, \\ Jimena Lema, M.D. ${ }^{b}$, José L. Pinheiro, Biochemist ${ }^{c}$, Adela Isasmendi, M.D. ', Verónica Álvarez, B.S. ${ }^{a}$, \\ Rosa M. Villasboas, M.D. ${ }^{b}$, Santiago Laborde, M.D. ${ }^{b}$ and Hugo Basilico, M.D. ${ }^{b}$
}

\begin{abstract}
Osteomyelitis is uncommon among burn patients.

Objective: To describe the clinical, microbiological, and evolutionary characteristics of burn children with osteomyelitis hospitalized in a tertiary care facility.

Methods: Retrospective and descriptive study conducted between January 2007 and January 2017.

Results: Out of 600 burn children, 12 developed osteomyelitis (incidence: $2 \%$ ). Eleven patients had a burn caused by direct fire. Patients' median age was 42.5 months (interquartile range [IQR]: 27-118 months), and their median burned surface area
\end{abstract}

a. Department of Epidemiological Control and Infectious Diseases.

b. Plastic Surgery and Burn Unit.

c. Department of Microbiology.

Hospital de Pediatría "Prof. Dr. Juan P. Garrahan,"

Buenos Aires, Argentina.

E-mail address:

María T. Rosanova, M.D.: margris2@yahoo.com.ar

Funding: None.

Conflict of interest: None.

Received: 4-11-2017

Accepted: 7-19-2017 was 33.5\% (IQR: 18.5-58\%). Osteomyelitis was diagnosed at a median period of 30 days following the burn injury. The most common locations were the upper limbs and the cranial vault. Fever was the most frequent clinical manifestation. The most common microorganisms isolated in bone tissue were fungi in 9 patients. All showed compatible anatomopathological findings. The treatment lasted a median of 44.5 days (IQR: 34.5-65.5 days). Six patients had motor sequelae and 1 died. Conclusion: Fungal osteomyelitis was the most commonly observed etiology. Half of patients had functional sequelae and only 1 patient died.

Key words: osteomyelitis, burn, child.

http: / / dx.doi.org/10.5546/ aap.2018.eng.59

To cite: Rosanova MT, Voto C, Carnovale S, et al. Osteomyelitis in burn children: Ten years of experience. Arch Argent Pediatr 2018;116(1):59-62.

\section{INTRODUCTION}

Osteoarticular infections secondary to burns are infrequent in the field of pediatrics. ${ }^{1}$ The extent of the burn surface area and burn depth, together with exposure of the structures beneath the skin, are predisposing factors. ${ }^{1,2}$ The clinical manifestations are subtle and differ from those of healthy hosts. An early diagnosis and treatment of 
this entity are critical to prevent related functional sequelae. ${ }^{1}$ The experience in pediatrics with osteomyelitis is scarce and limited to series that included few cases.

Objective. To describe the clinical, microbiological, and evolutionary characteristics of children diagnosed with osteomyelitis and hospitalized in the Pediatric Burn Unit of a tertiary care facility.

\section{POPULATION AND METHODS}

An observational, retrospective and descriptive study was conducted in the period between January 2007 and January 2017.

\section{Inclusion criteria}

Patients older than 1 month and younger than 18 years diagnosed with osteomyelitis and admitted to the Burn Unit of Hospital de Pediatría "Prof. Dr. Juan P. Garrahan."

\section{Definitions}

Osteomyelitis: microbiological isolation in bone tissue with compatible anatomopathological findings.

Garces' index: severity and mortality prediction index that is calculated as follows: 40 minus patient's age, plus burn wound percentage, multiplied time 1 (if type A burn injury), times 2 (if type $A B$ burn injury), and times 3 (if type B burn injury). From 0 to 60 points: grade 1 (mild), from 61 to 90 points, grade 2 (moderate); from 91 to 120 points, grade 3 (severe); above 121 points, grade 4 (critical). ${ }^{3}$

Type of burn: superficial (A), intermediate $(\mathrm{AB})$, and "full thickness" or deep (B).

\section{Microbiology}

Samples were processed for routine bacteriological tests and also for mycological tests. Blood agar, chocolate agar, cystine lactose electrolyte deficient (CLDE) agar, and thioglycolate broth were inoculated with the samples and incubated at $37^{\circ} \mathrm{C}$ for $24-72$ hours. Sensitivity tests to different antibacterial drugs were done using automated methods and disc diffusion methods, according to the Clinical and Laboratory Standards Institute (CLSI) Guidelines. ${ }^{4}$

Yeast fungi were identified using micromorphological tests, CHROMagar isolation, API 20 C Aux (bioMérieux), and proteomic tests (Vitek-MS bioMérieux). Filamentous fungi were identified using conventional techniques. ${ }^{5}$

\section{Data analysis}

Median and interquartile range (IQR) were adopted as position and dispersion measures.
Frequencies were described as percentage $(\%)$.

The endpoints of interest included complete recovery of patients without relapse or sequelae for at least 3 months following hospital discharge, and death during hospitalization.

\section{RESULTS}

Out of 600 patients hospitalized in the study period, 12 were diagnosed with osteomyelitis (incidence: $2 \%$ ).

Patients' median age was 42.5 months (IQR: 27-118). Burn mechanisms were direct fire in 11 patients and electricity in 1 . The median burned surface area was 33.5\% (IQR: 18.5-58). All patients had a type $A B$ and $B$ burn injury, and 7 patients had a Garces' index $\geq 3$.

Eleven patients had bone exposure upon admission and 7 , compartment syndrome of the affected site. All patients required invasive procedures. The median length of assisted mechanical ventilation was 25 days (IQR: $13-48$ days); central venous line use, 43 days (IQR: 29-66 days); and arterial line, 38.5 days (IQR: $14.5-58$ days).

Osteomyelitis was diagnosed at a median period of 30 days following the burn injury.

The clinical presentation was sepsis in 2 patients; 7 patients had fever and 1, hypothermia. Anatomic pathology was compatible with osteomyelitis in all cases. Fungal osteomyelitis was the most commonly observed etiology.

The median treatment time was 44.5 days (IQR: 34.5-65.5) and the median length of stay, 75 days (IQR: 76-82.5).

Complications were observed in 11 patients; 6 had motor sequelae and 4 suffered the amputation of the affected site. One patient died due to infection-related sepsis. Table 1 summarizes the main clinical, microbiological, and evolutionary characteristics of patients.

\section{DISCUSSION}

Osteomyelitis is uncommon among patients with burn wounds. Reports found in the bibliography are scarce and cover series that included few cases. ${ }^{1}$

In our study, osteomyelitis incidence was $2 \%$, which is consistent with other reported series. ${ }^{1}$

The pathogenic mechanisms of osteomyelitis in burn patients are different from those in healthy hosts. Deep burns with exposure of the underlying musculoskeletal structures and electrical burns lead to thrombosis in the periosteal nutrient vessels with bone tissue necrosis and contiguous infection. ${ }^{1,6,7}$ Bone exposure of the affected site was observed 
in 11 patients, and 7 of them developed compartment syndrome.

The burn mechanisms reported in the bibliography vary; ${ }^{8-11}$ however, in this series, direct fire burns predominated.

Location in the upper limbs was common among our patients, as observed in the study by Pandit et al., ${ }^{1}$ who reported hand involvement in $47.5 \%$; in other series, upper limb involvement secondary to direct fire and scald was also prevalent. 8

Rib osteomyelitis secondary to electrical burn has been reported in adults. ${ }^{10}$ Mullins et al. ${ }^{11}$ described an adult patient with burn wounds affecting $59 \%$ of his body surface area who developed Candida albicans spondylodiscitis. No patient in this series was affected in such locations. However, osteomyelitis in the cranial vault secondary to a burn injury has not been previously described in the consulted bibliography.

In relation to the clinical presentation, fever of variable duration or hypothermia may be the only signs of infection. The presentation of sepsis was uncommon in our patients, and no references were found in this regard in the bibliography. ${ }^{2,6}$

Microorganisms that cause infections in burn patients vary depending on the time and location of the burn injury. ${ }^{12}$

Fungal osteomyelitis was the most common etiology among these patients, with a median of 30 days elapsed after the burn injury. This would make it possible to infer that prolonged hospitalization, broad-spectrum antibiotics, and invasive procedures in these patients play a causative role.

In a published study on fungal infections in burn children, ${ }^{13}$ a burn surface area $\geq 30 \%$, central venous and arterial lines placement, and

TABLE 1. Patients' characteristics $(n=12)$

\begin{tabular}{|c|c|c|c|c|c|c|c|c|c|}
\hline $\begin{array}{c}\text { Age } \\
\text { (months) }\end{array}$ & $\begin{array}{c}\text { Burn } \\
\text { mechanism }\end{array}$ & $\begin{array}{c}\text { Burned } \\
\text { surface area } \\
(\%)\end{array}$ & Depth & $\begin{array}{l}\text { Garces' } \\
\text { index }\end{array}$ & $\begin{array}{l}\text { Osteomyelitis } \\
\text { location }\end{array}$ & $\begin{array}{l}\text { Bone tissue } \\
\text { culture }\end{array}$ & $\begin{array}{c}\text { Systemic } \\
\text { treatment/ } \\
\text { duration (days) }\end{array}$ & $\begin{array}{c}\text { Oral } \\
\text { treatment/ } \\
\text { duration } \\
\text { (days) }\end{array}$ & $\begin{array}{l}\text { Clinical } \\
\text { course }\end{array}$ \\
\hline 34 & Direct fire & 56 & $A B-B$ & IV & Cranial vault & Mucor spp. & $\begin{array}{c}\text { Amphotericin D/ } \\
\text { amphotericin LC } \\
\text { (47 d) }\end{array}$ & $\begin{array}{c}\text { Posaconazole } \\
\text { (30 d) }\end{array}$ & Deformity \\
\hline 37 & Direct fire & 60 & $A B-B$ & IV & Cranial vault & $\begin{array}{c}\text { Trichosporon } \\
\text { asahii }\end{array}$ & \begin{tabular}{|c|} 
Amphotericin D \\
(33 d)
\end{tabular} & $\begin{array}{c}\text { Voriconazole } \\
\text { (25 d) }\end{array}$ & Deformity \\
\hline 156 & Electricity & 12 & $A B-B$ & II & Left hand & $\begin{array}{c}\text { Candida } \\
\text { parapsilosis } \\
\text { Acinetobacter } \\
\text { baumannii }\end{array}$ & \begin{tabular}{|c|} 
Amphotericin D \\
$(14 \mathrm{~d})$ \\
Colistin \\
$(17 \mathrm{~d})$
\end{tabular} & $\begin{array}{l}\text { Fluconazole } \\
\text { (66 d) } \\
\text { Ciprofloxacin } \\
(66 \mathrm{~d})\end{array}$ & $\begin{array}{l}\text { Left hand } \\
\text { retraction }\end{array}$ \\
\hline 30 & Direct fire & 65 & AB-B & IV & Cranial vault & $\begin{array}{c}\text { Candida } \\
\text { parapsilosis }\end{array}$ & $\begin{array}{c}\text { Amphotericin D } \\
\text { (21 d) }\end{array}$ & $\begin{array}{l}\text { Fluconazole } \\
\text { (32 d) }\end{array}$ & Deformity \\
\hline 48 & Direct fire & 17 & $A B B$ & II & Left tibia & $\begin{array}{l}\text { Candida } \\
\text { albicans }\end{array}$ & $\begin{array}{c}\text { Amphotericin LC } \\
\text { (14 d) }\end{array}$ & $\begin{array}{c}\text { Fluconazole } \\
\text { (50 d) }\end{array}$ & Death \\
\hline 124 & Direct fire & 70 & $A B-B$ & IV & Right heel & Fusarium spp. & \begin{tabular}{|c|} 
Amphotericin LC \\
(37 d)
\end{tabular} & $\begin{array}{c}\text { Voriconazole } \\
(24 \mathrm{~d})\end{array}$ & Retraction \\
\hline 192 & Direct fire & 32 & $A B-B$ & III & $\begin{array}{l}\text { Left index } \\
\text { finger }\end{array}$ & $\begin{array}{c}\text { Candida } \\
\text { albicans } \\
\text { Pseudomonas } \\
\text { aeruginosa }\end{array}$ & \begin{tabular}{|c|} 
Amphotericin \\
$(14 \mathrm{~d})$ \\
Piperacillin \\
tazobactam \\
$(18 \mathrm{~d})$ \\
\end{tabular} & $\begin{array}{l}\text { Fluconazole } \\
(20 \mathrm{~d}) \\
\text { Ciprofloxacin } \\
(24 \mathrm{~d})\end{array}$ & Amputation \\
\hline 24 & Direct fire & 6 & $A-A B$ & II & Left big toe & $\begin{array}{c}\text { Pseudomonas } \\
\text { aeruginosa } \\
\end{array}$ & \begin{tabular}{|l|} 
Colistin (46 d) \\
\end{tabular} & & Amputation \\
\hline 60 & Direct fire & 50 & B & III & $\begin{array}{l}\text { Right } \\
\text { fibula } \\
\end{array}$ & $\begin{array}{c}\text { Pseudomonas } \\
\text { aeruginosa } \\
\end{array}$ & Colistin (42 d) & & Deformity \\
\hline 3 & Direct fire & 20 & B & II & Right foot & $\begin{array}{c}\text { Enterococcus } \\
\text { faecalis }\end{array}$ & $\begin{array}{l}\text { Piperacillin } \\
\text { tazobactam } \\
(25 \mathrm{~d})\end{array}$ & $\begin{array}{l}\text { Amoxicillin } \\
\text { (18 d) }\end{array}$ & Amputation \\
\hline 36 & Direct fire & 35 & $A B-B$ & IV & $\begin{array}{l}\text { Right index } \\
\text { finger }\end{array}$ & Fusarium spp. & $\begin{array}{c}\text { Voriconazole } \\
(10 \mathrm{~d})\end{array}$ & $\begin{array}{c}\text { Voriconazole } \\
(30 \mathrm{~d})\end{array}$ & Retraction \\
\hline 138 & Direct fire & 26 & $A B-B$ & II & $\begin{array}{l}\text { Left little } \\
\text { finger }\end{array}$ & Fusarium spp. & $\begin{array}{c}\text { Voriconazole } \\
\text { (20 d) }\end{array}$ & $\begin{array}{c}\text { Voriconazole } \\
\text { (22 d) }\end{array}$ & Amputation \\
\hline
\end{tabular}

D: deoxycholate; LC: lipid complex. 
prolonged use of broad-spectrum antibiotics were identified as risk factors for infection and were observed in all patients with fungal osteomyelitis.

Pseudomonas aeruginosa infection was also observed, which has been described in relation to the length of stay in the hospital, microorganism virulence factors, and invasive procedures. ${ }^{12}$

Treatment duration in this entity has not been clearly defined. In our series, it varied and included prolonged, sequential intravenous-oral administration, depending on the clinical course and the microorganism. In all cases, surgical drainage was performed, which is considered the cornerstone of osteomyelitis management. ${ }^{1,2}$

Functional sequelae are common with this entity. ${ }^{1-7}$ Half of patients in this series developed this type of sequelae. Four suffered the amputation of the affected site.

No other study has assessed mortality in burn patients with osteomyelitis. Among our patients, 1 died due to osteomyelitis-related sepsis.

The limitations of this study include its small sample size, which hinders the possibility of creating a model of risk factors for osteoarticular infection in this type of patients. Also, the study design was not adequate to assess the effectiveness of the implemented treatment strategies.

The main strength of this study was the 10 years of experience in burn children at a tertiary care hospital and the fact that, to our knowledge, it is the largest case series published in this age group.

\section{CONCLUSIONS}

Osteomyelitis was uncommon among pediatric burn patients. Fungal osteomyelitis was the most commonly reported etiology. Fever was the most frequent clinical manifestation. Half of patients had functional sequelae and only 1 patient died.

\section{REFERENCES}

1. Pandit SK, Malla CN, Zarger HV, et al. A study of bone and joint changes secondary to burns. Burns. 1993;19(3):227-8.

2. Barret JP, Desai MH, Herndon DN. Osteomyelitis in burn patients requiring skeletal fixation. Burns. 2000;26(5):487-9.

3. Garcés M, Tapia L, Hoecher F, et al. Clasificación y pronóstico de los quemados. Rev Asist Pública de Santiago. 1971;1:5-9.

4. Patel J, CockerillF, Bradford P, et al.M100-S25. Performance Standards for AntimicrobialSusceptibility Testing; TwentyFifth Informational Supplement. Wayne, PA: Clinical and Laboratory Standards Institute; 2015;35(3):1-16. [Accessed on: June 19 $\left.19^{\text {th }}, 2017\right]$. Available at: https://www.google. com.ar $/$ url? sa $=$ t\&rct $=j \& q=\& e s r c=s \&$ source $=$ web\& $c d=1$ $\&$ cad $=$ rja\&uact $=8 \&$ ved $=0$ ahUKEwi8gbHGkZjVAhXChp AKHZkTAeUQFggnMAA\&url=https $\% 3 \mathrm{~A} \% 2 \mathrm{~F} \% 2 \mathrm{Fwww}$. researchgate.net $\% 2$ Ffile.PostFileLoader.html $\% 3$ Fid $\% 3 \mathrm{D} 58$ 1d9d8fcbd5c2f99c04d4b1\%26assetKey\%3DAS\%253A4249 $85668919296 \% 25401478335887189 \& u s g=A F Q j C N G P T b 4 t h$ WEELSAen57wBDDO-QH5Zg.

5. Canteros C, Davel G, Tiraboschi N, et al. Curso teóricopráctico: El Laboratorio y el Diagnóstico de las Micosis Sistémicas. Buenos Aires: Diagnóstico de Micosis Sistémicas. Departamento Micología. INEI. ANLIS "Carlos G. Malbrán"; 2012. [Accessed on: June 19", 2017 ]. Available at: http:/ / www.anlis.gov.ar/inei/micologia/ wp-content/uploads / 2016/05/guia\%C2\%ADa-Cursoteorico-practico-micosis-sistemicas.pdf.

6. Evans B. Musculoskeletal changes secondary to thermal burns. In Herndon D. Total Burn Care. 4th ed. Philadelphia: Saunders; 2012:551-64.e2.

7. Lollo L, Grabinsky A. Clinical and functional outcomes of acute lower extremity compartment syndrome at a Major Trauma Hospital. Int J Crit Illn Inj Sci. 2016;6(3):133-42.

8. Fodor L, Peled I, Lerner A, et al. Acute osteomyelitis after a minor, 2nd degrees burn of the finger. Burns. 2004; 30(2):185-7.

9. Asamura S, Fukunishi K, Matunaga K, et al. A Baby with Osteomyelitis after a Grade II Burn. Plast Reconstr Surg 2007;120(4):1089-90.

10. Alffie M, Benmeir P, Caspi R, et al. Costal osteomyelitis due to an electrical burn. Burns. 1995;21(2):147-8.

11. Mullins RF, Still JM Jr, Savage J, et al. Osteomyelitis of the spine in a burn patient due to Candida albicans. Bums. 1993;19(2):174-6.

12. Rosanova MT, Stamboulian D, Lede R. Infecciones en los niños quemados: análisis epidemiológico y de los factores de riesgo. Arch Argent Pediatr. 2013;111(4):303-8.

13. Rosanova MT, Basilico $H$, Villasboas M, et al. Infecciones fúngicas enuna unidad de quemados pediátrica. Arch Argent Pediatr. 2011;109(5):437-44.

\title{
Opioid treatment for mixed pain in pediatric patients assisted by the Palliative Care team. Five years of experience
}

\author{
María L. Yazde Puleio, M.D. ${ }^{a}$, Karina V. Gómez, M.D. ${ }^{a}$, Ana Majdalani, M.D. ${ }^{a}$, Vilma Pigliapoco, B.S. ${ }^{a}$ \\ and Gisella Santos Chocler, M.D. ${ }^{a}$
}

a. Hospital General de Niños Pedro de Elizalde, Palliative Care Task Force, Autonomous City of Buenos Aires.

E-mail address:

María L. Yazde Puleio, M.D.: mliliyp@gmail.com
Funding: None.

Conflict of interest: None.

Received: 4-9-2017

Accepted: 8-15-2017 